\title{
Farmasi Lilla
}

\section{Mesterséges határok:}

\section{A természettudományok és humán tudományok viszonyáról, eredményeiról és módszereiról}

\begin{abstract}
Absztrakt
A tanulmány a diszciplináris határok jelentôségével, illetve a különbözố tudományterületek egymáshoz viszonyított pozíciójával foglalkozik. A jelenleg egy-egy diszciplínán belüli és tudományközi kutatásokban is tapasztalt, bábeli zúrzavarhoz hasonlítható helyzet kialakulását és természetét igyekszik megérteni különös tekintettel a gyakran egymás ellentéteként elképzelt humán és természettudományok viszonyát illetôen. Vizsgálódásában példaként a kognitív- és idegtudomány irodalomelméletben történő alkalmazásait veszi górcsô alá.

Szerzó

Farmasi Lilla (1989) jelenleg a Szegedi Tudományegyetem Angol-Amerikai Intézetének tudományos segédmunkatársa, doktorjelölt. Disszertációjában a tér- és mozgásészlelés szerepét vizsgálja narratív struktúrákban. Kutatási területe a kognitív elméletek, a huszadik századi amerikai irodalom, a posztklasszikus narratológiák, illetve a narratív elméletek interdiszciplináris kutatásokban, különösen a pszichiátriában és pszichológiában történó felhasználása. E-mail: farmasililla@gmail.com
\end{abstract}

https://doi.org/10.31176/apertura.2019.14.3.6 


\section{Farmasi Lilla}

\section{Mesterséges határok:}

\section{A természettudományok és humán tudományok viszonyáról, eredményeiról és módszereiról}

\section{Bevezetó}

A jelen tanulmány a diszciplináris határok helyével és jelentôségével, illetve a különbözô tudományterületek egymáshoz viszonyított pozíciójával foglalkozik, különös tekintettel a gyakran egymás ellentéteként elképzelt humán és természettudományokra. ${ }^{[1]} \mathrm{Az}$ interdiszciplináris kutatások példájaként a jelen tanulmány a két területet ötvözô, a 90-es években megjelent és azóta roppant népszerüvé vált kognitív narratológiát veszi górcsô alá, mivel a hagyományosan egymással ellentétesként tételezett humán tudományok és természettudományok ${ }^{[2]}$ együttmúködésére és az interdiszciplináris kutatás problémáira egyaránt kiváló példa a narratív elméletek jelenlegi helyzete. Ennek bemutatása után a tanulmány az utóbbi évtizedekben a kognitív elméletek és az általuk kikövezett úton haladó idegtudomány humán tudományokban történó alkalmazhatóságát, illetve a neuroregény „múfaját” vizsgálja, mint a két „ellentétes” terület lehetséges ötvözetét. A vizsgálat segítségével arra a triviálisnak tûnô problémára igyekszik rávilágítani, hogy a jelenleg legfontosabb kérdés nem pusztán az, hogyan érhetünk el újabb eredményeket különböző tudományterületek eredményeinek együttes felhasználásával, hanem az is, hogy alapvetôen hogyan közelíthetünk egyik tudományterület felôl egy másikhoz.

Az 1950-es években megindult kognitív forradalom, mely során tudományos igénnyel kezdték kutatni az emberi viselkedés mögött munkálkodó, a tudatban zajló folyamatokat, számos tudományterület munkájából merített, és számos tudományterületet inspirált a pszichiátriától az irodalomelméletig. A tudat „elóállításának” legfontosabb (egyes vélemények szerint egyetlen) komponense, az agy múködésének kutatása ugyan sok szempontból gyerekcipóben jár, de az „agy évtizedének" is nevezett kilencvenes évek óta az idegtudomány egyre nagyobb teret hódít, rohamos ütemben fejlődik, és gyors ütemben halmozza az emberi agyról megszerzett tudásunkat. Pontosabban szólva csak következtet az emberi agyra, hiszen az agykutatók leggyakrabban egereken vagy más, egyszerúbb lényeken, például tengeri csigákon ${ }^{[3]}$ végzik a kísérleteiket - az emberi agyon végzett vizsgálatok pedig csak külön interpretáció segítségével hoznak eredményeket. ${ }^{[4]}$ Persze az ezekhez hasonló fenntartásokat nem egészen önkényesen teszi zárójelbe az idegtudomány, mely gyakran tett radikális felfedezéseket az elmúlt években. Átfogó 
agymodell hiányában azonban, melybe az új felfedezések rendre beilleszthetôek volnának, az ezekból az eredményekből levonható legbiztonságosabb konklúzió többnyire az, hogy az agy és annak múködése bonyolultabb, mint korábban hittük. Bölcsészként erre a problémára megnyugtató lenne az idegtudomány sajátjaként tekinteni, azonban amellett, hogy az összetettség általános jellemzôje minden területnek, a tudományközi kutatások egyik eredményeképpen a diszciplínák olykor több problémát örökölnek egymástól, mint amennyi eredménnyel járnak. A következôkben többek közt ennek az állapotnak a kialakulásával és jelenlegi körülményeivel foglalkozom. A klasszikus és posztklasszikus narratológiák közti különbség és a kognitív- és neuronarratológiák múködésének vizsgálata véleményem szerint segítheti e probléma megértését.

\section{Diszciplináris határok}

A diszciplínák szigorú körülhatárolása a „karteziánus tudomány” gyakorlatában gyökerezik, amely „[a]z élô és élettelen közötti alapvető diszkontinuitást” tételezte, és amely megszabta, melyik tudományterületnek mit kell kutatnia:

Az élôvel foglalkozó tudományok (biológia, orvostudomány, fiziológia, pszichológia) ezt a diszkontinuitást és mintaképet elfogadva, a dualizmus talaján jöttek létre. A kialakult munkamegosztás szerint a fizika területe a holt anyag, a biológiáé az élô anyag, az orvostudományé a test, a pszichológiáé a lélek, tudat és ráció. Élet, értelem, sors, szabadság, spontaneitás természeten kívül rekedt kérdéseire a hermeneutikai hagyomány kereste a választ, [...] a tudomány nem foglalkozik olyan problémákkal, mint érték, tudat, szabadság, a hermeneutikai hagyomány pedig nem foglalkozik azzal, hogy érték, tudat, szabadság hogyan kötôdnek a természeti világhoz és nem használja a tudományos megismerés módszereit. (Szokolszky 1998: 276)

Ez a felosztás gyakran problémákat vet fel, amelyek azonban esetenként reflektálatlanok maradnak. A 2018. ôszén megrendezett, XVII. Forum Humanum - Szegedi Pszichológiai Napok 2018 címú rendezvényen az agykutatás jelenlegi állását tárgyaló elôadás absztraktja ${ }^{[5]}$ azt vetítette előre, hogy az elôadás számba veszi az agymúködés kutatásának történetét a kezdetektôl, majd napjaink megközelítésébe ad betekintést. A kiinduló állapotot is említette az összefoglaló, jelesül, hogy Descartes idejében a fizika korabeli állása szerint igyekeztek modellezni az idegrendszer múködését, akkoriban a hidraulikus szerkezetek logikájával. A fenti felosztást alapul vevő közönség joggal várhatta, mikor tér rá az elôadó annak a fordulatnak a bemutatására, melynek során a kutatók megváltak az előfeltevéstôl, hogy az idegrendszeri folyamatokat a fizika törvényeinek segítségével modellezzék. ${ }^{[6]}$ Ez a pillanat azonban nem jött el. A karteziánus felosztás szerinti, az élô és élettelen anyag közötti megkérdôjelezetlen szakadék problémáját ez a módszer figyelmen kívül hagyja, és élô szervezetet vizsgál a holt anyag múködéseinek elvei szerint. Ennél még fontosabb, a diszciplináris határokat is érintô kérdés, hogy lehet-e az agy múködésével úgy 
foglalkozni, hogy nem foglalkozunk az emberi tudattal.

\section{A két(?) kultúra}

A kritikai kultúratudományhoz tartozó „két kultúra” kifejezés C. P. Snow angol fiziko-kémikus és regényíró 1959-ben a Cambridge-i Egyetemen tartott elôadásából származik. Az elôadásban Snow kifejezetten a természettudomány és az irodalomtudomány múvelöinek egymástól való elszigeteltségét, a brit társadalom szociológiai, múveltségszerkezeti tagoltságát és az ebbôl következő problémákat taglalja. Snow a két terület kutatóinak munkájára nem tér ki, azonban azt kijelenti, hogy a két kultúrának sajnálatos módon alkalma sincs találkozni (Snow, Collini 2012: 16). Az interdiszciplináris kutatások esetében azonban épp ez történik. A két terület olykor kifejezetten ellenséges viszonya (Snow, Collini 2012: 4) sokszor meghatározza és nagyban megnehezíti az ilyesfajta kutatásokat.

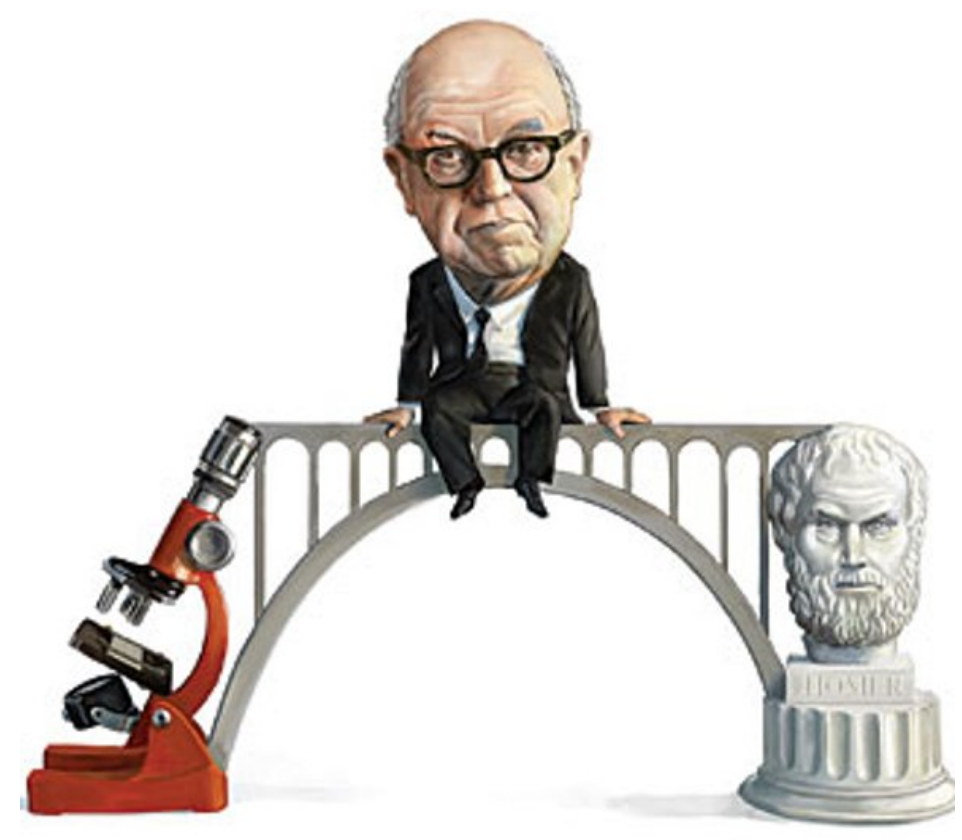

C. P. Snow a két kultúrát összekötô hídon

Az egyik leghíresebb, bölcsész és természettudós közötti eszmei vita Paul Ricoeur és Jean-Pierre Changeux 1998-ban lezajlott vitája, magyarul A természet és a szabályok címmel jelent meg. A vita elôtt Changeux és Ricoeur felhívják a figyelmet a két terület legfontosabb általános jellemzôire és problémáira:

A tudomány oldalán a közvélemény előítéleteivel kell szembeszállni. A közvélemény többnyire bízik a tudományban, sôt lelkesedik iránta, ugyanakkor kétkedéssel és gyanakvással szemléli, ahogy a tudomány az életet értelmezi s tart a közös jövôre nézve fenyegetônek érzett tudományos eredményektôl. ${ }^{[7]}$ A filozófiát illetôen pedig egy olyan 
diszciplína narcizmusát kellett megbontani, mely saját túlélésével van elfoglalva, s mivel hatalmas örökségének nyomasztó terhe alatt él, általában kevéssé érdeklik a tudomány újabb fejleményei. ${ }^{[8]}$ (Changeaux, Ricoeur 2001: 7)

Changeaux és Ricoeur az „ellentmondást nem tưrô állítások, egyoldalú bírálatok, érthetetlen mellébeszélések és könnyed gúnyolódás" (Changeaux, Ricoeur 2001: 8) helyett a plauzibilis, megfontolandó érveket hiányolják.

Bár a területek szembeállításának hagyománya van, többen rámutattak már, hogy ez a viszony amellett, hogy káros a tudományos munka szempontjából, alapvetóen nem is természetes. Vlagyimir Nabokov regényíróként szerzett világhírnevet, de természettudósként is múködött egész életében; entomológiai témájú tanulmányokat írt. Amikor egy interjúban arról kérdezték, hogy mit gondol a „két kultúra” feltételezett ellentétérôl, kifejtette, hogy ez a két kultúra egyrészt haszonelvú technológiák gyártásából, másrészt B-kategóriás regényekből, ideologikus fikcióból és populáris múvészetból áll. Nabokov csupán annyit jegyez meg, hogy teljesen hidegen hagyja, ha ilyen tudomány és ilyen bölcsészet között szakadékot találunk (Nabokov 2011: 67). Nem nehéz a sorok között kiolvasni azt a meglátást, hogy a természettudomány és a bölcsészet, illetve múvészetek között ideális esetben korántsincs ellentét. Egy másik interjúban Nabokov újfent a két, általa múvelt területrôl mesél, és szintén felülírni látszik ezek sztereotip megítélését, amikor „a költészet pontosságát és a tudomány izgalmát” emeli ki, mint meghatározó jellemzôket (Nabokov 2011: 9. Saját ford. FL).

Az amerikai írónő, Siri Hustvedt különleges „kettôs életet” él (Louisiana Channel 2018), mint regényíró és mint neurológiai témájú tudományos cikkek szerzôje. Hustvedt egyre több együttmúködést lát a természettudomány, bölcsészet és múvészetek között, amelyet üdvözöl, sốt szükségesnek tart. Emellett kiemeli azt az általános meglátást is, hogy a nyugati kultúra rendszerint a tudományt férfias jegyekkel ruházza fel, míg a múvészetek és a bölcsészet feminin területként aposztrofálódik, az elóbbi mint megbízható és komoly, az utóbbi mint nehezen megfogható, többé-kevésbé képzeletbeli (Louisiana Channel 2018). Ez a megközelítés egyenes úton vezet ahhoz az igazságtalan helyzethez, hogy a természettudományt a humán tudományokhoz viszonyítva alapvetôen többre értékeljük (Louisiana Channel 2018). Ideális esetben a két terület között elképzelt szakadék áthidalásának eszköze lehetne a kognitív narratológia vagy a Ralph Schneider által leírt, épp születốben lévố neuronarratológia (Schneider 2017).

\section{Narratológiák és interdiszciplinaritás}

A narratológiában mindig is történtek erôfeszítések arra, hogy a két különbözőnek értett tudást szisztematikus módon boronálják össze (Sommer 2017: 598), ezért tekinthetjük úgy, hogy eleve ötvözni igyekezett a humán és természettudományos szemléletet. Emiatt lehet a narratológia kiváló színtere az interdiszciplináris kutatásoknak, amit mindennél jobban példáz az, hogy milyen exponenciális (és exponenciálisan szerteágazó) növekedésen ment keresztül a terület az elmúlt 
évtizedekben.

A narratív elméletek mind az irodalom- és kultúratudományon belül, mind azon kívül meglehetôsen népszerûvé váltak az elmúlt évtizedekben. Mindez az elméletek olyan mértékú pluralizálódását eredményezte, amelyre a kortárs, posztklasszikus narratológiában és tágabb értelemben a narratív elméletekben Sandra Heinen és Roy Sommer csak „bábelizációként” utal ${ }^{[9]}$ (Heinen, Sommer 2009: 2). A narratív elméletekben ekkorra már bôven akad példa a „kemény” tudományok integrálására: megjelenik például a kognitív tudomány, a pszichológia és a mesterséges intelligencia kutatás is. Ansgar Nünning részletes táblázatokban igyekszik kategorizálni a posztklasszikus narratológiákat. Az irodalom- és kultúratudományokra szorítkozva is nyolc nagyobb alkategóriát és azokon belül számos megközelítést rendszerez (Nünning 2003); így is szinte átláthatatlan mennyiségú megközelítést gyưjt össze. Az egyéb területeken múködô elméleteket egy nagyobb kategóriába sorolja és narratív elméleteknek nevezi. Ezek már az irodalomelméletben létezô narratológiától legtöbbször teljesen függetlenül múködnek.

A posztklasszikus narratológiák egy részének egyik nagy vívmánya, hogy górcsô alá veszik a narratívák kontextusát. A strukturalizmusból született (klasszikus) narratológia szándékosan hagyta figyelmen kívül a történetek és a történetmondás társadalmi, történelmi, kulturális és egyéb környezetét, amelyet késôbb a posztklasszikus, például feminista, posztkoloniális, kognitív narratológiák tettek meg kutatásuk tárgyául. A klasszikus megközelítés képviselói ebben az eltolódásban az addig „tiszta” narratológia „megfertôzését,” „beszennyezését” vélik felfedezni (Nünning 2003: 255), részben ezen megközelítések kritikája fedezhetô fel például az ENN [European Narratology Network] 2017-es, Prágában megrendezett konferenciájának programjában, amelynek felhívásában egész egyszerúen a „struktúra” volt a központi téma, és kifejezetten a strukturalista múlt visszatérését hangsúlyozta. Wolf Schmid elôadásában szót is emelt a kontextualista narratológiák, például a feminista narratológia ellen. A strukturalista megközelítés visszatérését leginkább azok szorgalmazták, akik a strukturalizmus idején kezdték karrierjüket, s ezáltal úgy tûnt, mintha a rendezvény a strukturalizmusnak az azóta roppant népessé vált narratív elméletek élvonalába történô tudatos visszavezetését is célozta volna. Matias Martínez a narratológiai kutatások nehézségeit tárgyaló tanulmányában ${ }^{[10]}$ (Martínez 2012) felelôssé teszi többek közt a fiatal kutatókat, akik a jelenlegi tengernyi kortárs narratív elmélet sokaságában nem hajlandóak visszatekinteni és számításba venni a diszciplína korábbi fontos eredményeit. 
A kognitív narratológia módszereinek nyomán szintén a strukturalizmus visszatérésérekövetkeztet Dan Shen (Shen 2005) is, aki azonban nem kritizálja a kontextualista narratológiákat,sôt, többek közt amellett érvel, hogy a kontextualista és formalista megközelítéseknek kölcsönösenszükségük van egymásra (Shen 2005). A strukturalizmus „újraélesztésének” ügye akkor problémás,ha kizárólagossá igyekszik válni más módszerekkel szemben. A posztklasszikus narratológia sem a klasszikus (strukturalista) narratológia kritikájaként értelmezi magát, inkább annak bővítéseként. A bóvítés pedig egyéb tudományterületekkel, illetve új korpuszokkal, esetleg ezek együttes használatával történik (Herman 2009: 31).

A kognitív narratológia ${ }^{[11]}$, mivel a befogadóra koncentrál, kontextualista irányzatnak tekinthetô, módszereiben azonban valóban nagyrészt a strukturalizmusra támaszkodik. Emellett erôsen interdiszciplináris megközelítés, tekintve, hogy az ebben az esetben a narratológiával ötvözött kognitív tudomány számos tudományterületbôl merít. Maga a kognitív narratológia sem egységes terület, jelentôs eltérések találhatók különbözô kutatók munkáiban ${ }^{[12]}$, amelyek legtöbbször a kognitív elméletekból megörökölt problémára vezethetốk vissza, mivel az emberi kogníció múködéséról több, egymásnak ellentmondó elképzelés verseng.

Az elsô, az ötvenes években a számítógéppel párhuzamosan népszerúvé váló, ún. kognitivista irányzat a kogníciót mint minden kontextustól független szimbólummanipulációt értelmezte, röviden a kogníciót a komputáció mintájára képzelte el. A kognitivizmus tehát megtartotta az élettelen anyag és a testetlen értelem dualizmusát és a kettô közötti alapvetô diszkontinuitást (Szokolszky 1998: 276). Legtöbbször ezen elképzelés kritikájának tekintik az ún. második generációs kognitív elméleteket, avagy a kognitivizmus posztkarteziánus alternatíváit, amelyek, noha szintén nem egységesek (Ryan 2012: 174), abban megegyeznek, hogy az emberi tudatot és kogníciót az elme, a test és a környezet interakciójának eredményeképpen igyekeznek megérteni. Ezekben az elképzelésekben az elemzések alapegysége a dinamikus test-elme-környezet rendszer. A megközelítés erôsen kötődik mind a természettudományhoz, mind a bölcsészethez, így szükségszerúen interdiszciplináris. 


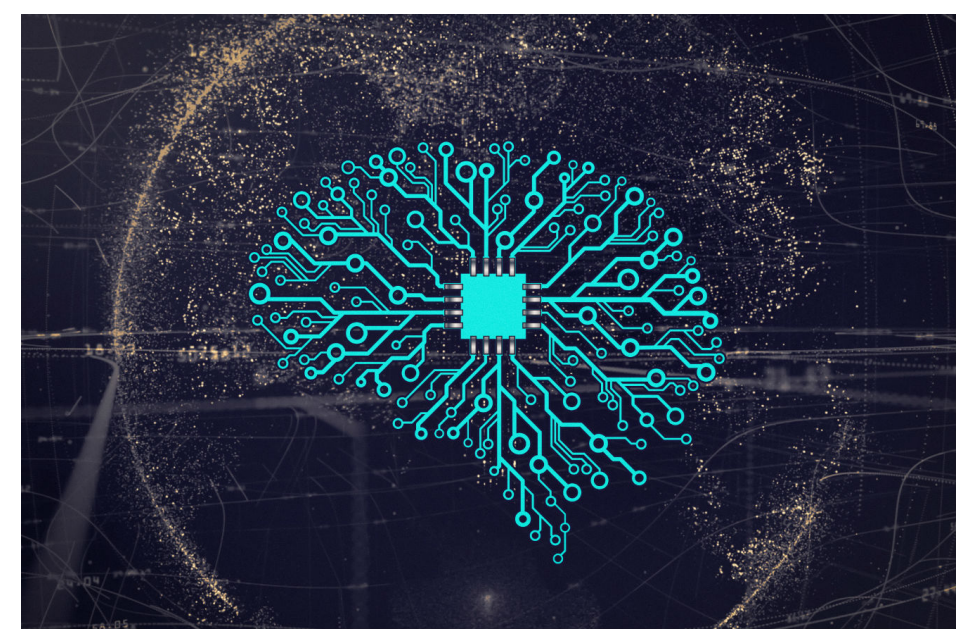

Mike Mackenzie: Machine Learning and Artificial Intelligence.

Forrás: www.vpnsrus.com

A 21. század elejére az interdiszciplinaritás olyan gyakran használt kifejezéssé vált, hogy a tudományos munkában alapvetônek tûnhet. Az, hogy valódi interdiszciplinaritásról beszélhetünke vagy csak egyirányú átvételekrôl különbözô (noha leggyakrabban meglehetôsen közeli) területekrôl, már jóval kevésbé egyértelmú. Sandra Heinen például arra figyelmeztet, hogy a narratológiának a pszichológiában és pszichiátriában történô alkalmazása sokszor nem jelent többet a strukturalista narratológia néhány fogalmának átvételénél (Heinen, Sommer 2009: 194), holott ezeken a területeken jó eséllyel volnának relevánsak a kognitív narratológiában kidolgozott és újragondolt fogalmak. A narratív tudományok kutatásai gyakran egymástól teljesen elszigetelve folynak, így például egy pszichológus vagy egy történész, aki narratív elméletekkel dolgozik a saját területén, jó eséllyel magát a narratíva kifejezést is metaforikusan használja, ${ }^{[13]}$ és megkerüli a narratíva definícióit övező vitákat (Hyvärinen 2010). Azok a kutatók, akik valóban nyitottak az interdiszciplináris munkára, többnyire narratológusok, akik először az irodalomelmélet területén szereztek képesítést, és azután ismerkedtek közelebbrôl más területekkel (Sommer Heinen 2009: 2).

\section{A neuroregény és a neuronarratológia}

A kognitív fordulattal a bölcsészettudomány nagy lépést tett a természettudományok felé, a narratív fordulattal pedig a többi tudományterület tehet(ett volna) nagy lépést az irodalomtudomány felé. ${ }^{[14]}$ Az interdiszciplináris elméletekben az egyik legújabb, teret hódító természettudományos diszciplína a neurológia, amelynek alkalmazási kísérletei felfoghatók a kognitív elméletekhez tartozó új kísérletekként, illetve a „kemény” tudományok irányába történô újabb lépésként. Egy humán tudományokkal foglalkozó kutató szemében legalábbis ez a terület valószínúleg egyértelmúen az egzaktabb tudományok közé sorolandó. Épp ezért meglepô lehet a neves neurológus, V. S. Ramachandran ${ }^{[15]}$ nézôpontja, miszerint az idegtudomány is egy azon területek közül, amelyek kissé „megfélemlítve”, alulról szemlélik a „kemény” tudományokat. Miután évtizedekig küszködött ezen tudományok árnyékában (Ramachandran 2012: x), az 
idegtudomány mostanra népszerúvé vált, sôt, a magabiztosság azon fokát is elérte, hogy eredményeit olyan problémák vizsgálataira is szentelhesse, amelyek hagyományosan a humán tudományok fennhatósága alá tartoznak (Ramachandran 2012: ix). Ilyen például az esztétika, amelyen belül a neuroesztétika ${ }^{[16]}$ a múvészi élmény mögötti agyi tevékenységet és a kettô közötti összefüggést kutatja.

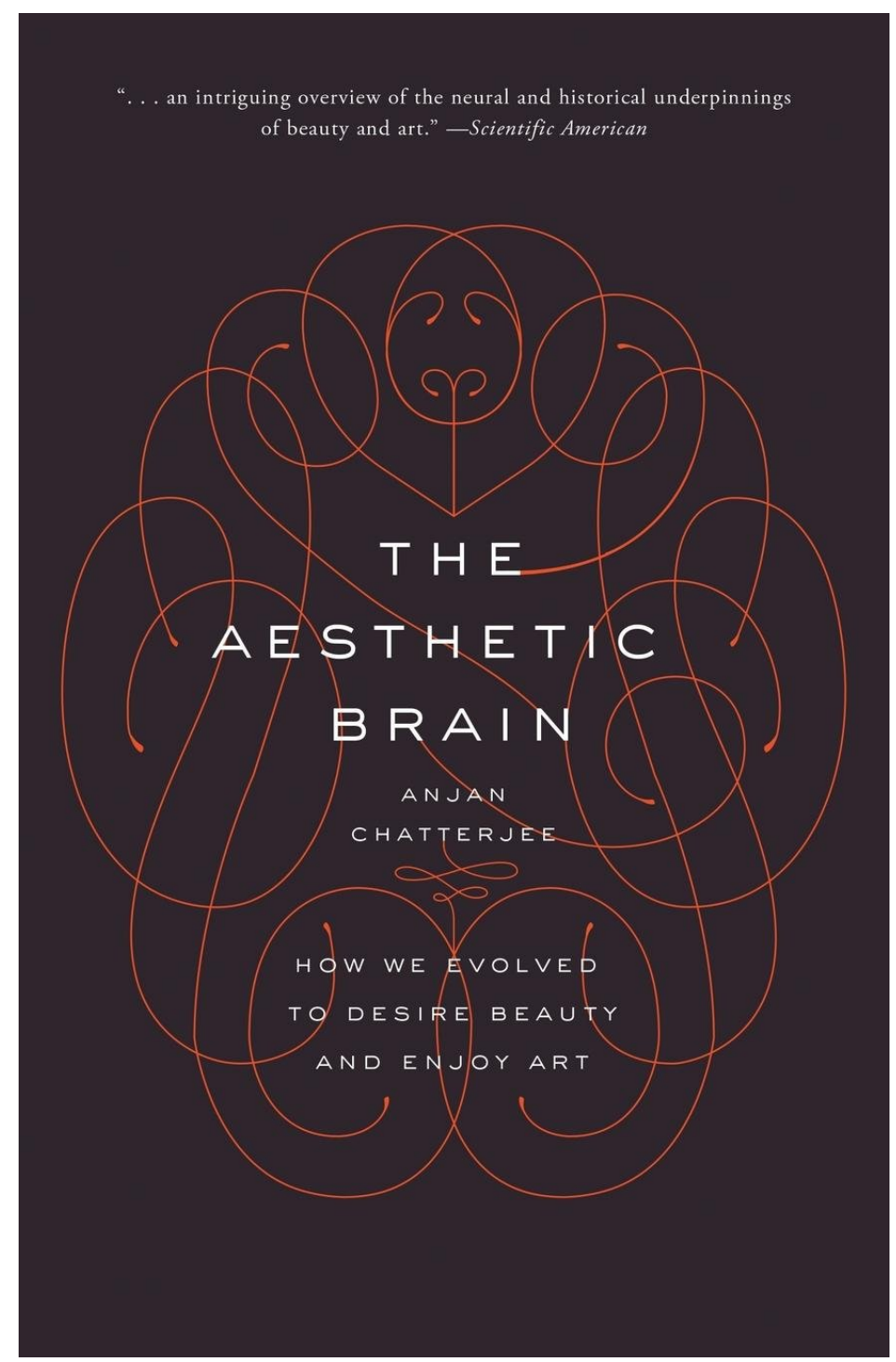

Chatterjee The Aesthetic Brain cimü könyvének boritója 
A neurológia elméletei a pszichológiában már korábban, a 80-as évektôl jelentôssé váltak, amikor Ramachandran becslése szerint a kutatóknak sikerült meghaladniuk az idegtudomány bronzkori állását (Ramachandran 2012: xi). Ramachandran nem álszerénységból fogalmaz így, tisztában van vele, hogy mára divatos területté vált a neuromarketing, neuropolitika, neuro-közgazdaságtan és a neuroépítészet is. Ezek közül ugyan némelyik csupán a „neurohájp” terméke (Ramachandran2012: xi), az irodalomelméletben azonban, ahol a kognitív elméletek már viszonylag régen utattörtek a természettudományok alkalmazásában, és ahol egyre nagyobb hangsúlyt kap az emberitest ${ }^{[17]}$ fiziológiájának számbavétele, valóban ígéretesnek mutatkozik az idegtudományeredményeinek beépítése.

Ralph Schneider 2017-es írása az épp születôben lévő terület, a neuronarratológia lehetôségeit és lehetséges zsákutcáit veszi számba. A neuronarratológia módszerét érdeklődéssel vegyes gyanakvással vizsgálja, és megjegyzi, hogy korai lenne messzemenô következtetéseket levonni a jövôjét illetôen (Schneider 2017). A neuronarratológiánál, azaz az idegtudomány eredményeinek a narratológiába történő integrálásánál Schneider szerint az alapvetố kérdés az, hogy a percepció vagy az emlékezet fiziológiájának jelenlegi neurobiológiai modelljei segítenek-e megválaszolni a narratológusok korábbi kérdéseit (Schneider 2017: 483), legfóképp azt, hogy hogyan keletkezik a narratív jelentés (Schneider 2017: 485). Schneider állítása szerint agyi képalkotó diagnosztikai eszközök segítségével különbözô agyterületek aktiválódását figyelni „nevetségesen alkalmatlan” módszer a narratív megértés vizsgálatára (Schneider 2017: 485), tanulmányában azonban mégis neurobiológiáról, sejtszintû folyamatokról beszél. A probléma itt is a mentális és testi (agyi) folyamatok közötti szakadék. Az idegtudomány és a narratív elméletek azonban potenciálisan közös lépést tehetnének a neuropszichológia elméleteinek alkalmazásával, hiszen ez a diszciplína kifejezetten az agy és a tudat múködése közti kapcsolatokkal foglalkozik, és talán hozzásegíthetne a kettố közötti szakadék áthidalásához. Nem mellesleg a neuropszichológia módszertan tekintetében könnyen összeegyeztethetố a megtestesült elme tudományával.

Az idegtudomány napjainkban nem csak a humán tudományokban, hanem a múvészetekben is megjelenik, és ez talán példája lehet annak a kulturális jelenségnek, amelynek hiányáról korábban C. P. Snow értekezett a „két kultúra” egymástól való teljes elszigeteltségének kapcsán. A természettudomány, azon belül is az idegtudomány, irodalomba ágyazását kísérli meg az angolszász prózában az elmúlt évtizedekben megjelenő, Marco Roth által múfajként aposztrofált neuroregény. Roth, aki tanulmányt szentelt a jelenségnek, úgy számítja, hogy a szóban forgó irodalmi múvek ${ }^{[18]}$ az 1990-es években, az agy évtizedében ${ }^{[19]}$ kezdtek megjelenni. Roth szerint a neuroregény a pszichológiai regény és más, tudatábrázolással foglalkozó múvek helyét veszi át, méghozzá azzal a lépéssel, hogy a tudat helyett az agyra koncentrál.

A neuroregény felfogható azon tendencia részeként, amely során az empirikus és természettudományok a tudományos és a hétköznapi életben is egyre dominánsabbá válnak, mind a tudományos igényú munkában, mind a popkultúrában ${ }^{[20]}$. A neuroregényekben a fốszereplố rendszerint egy kognitív vagy idegrendszeri problémákkal küzdô személy, a regény 
jelentôs mértékben ennek a szereplônek a tudatával foglalkozik. Így egy olyan típusú karakter kerül a történetek középpontjába, amely korábban szinte csak mellékszereplóként jelenhetett meg (Roth 2009). Roth példája szerint úgy kell elképzelnünk egy ilyen múvet, mintha William Faulkner $A$ hang és a téboly címú regényének elbeszélôje végig egyedül Benjy lenne (Roth 2009). Ide tartoznak olyan múvek, mint Jonathan Lethem Tourette-szindrómás fôhôst szerepeltetô Arva Brooklynja (1999), John Wray Lowboy (2009) címú regénye, melynek fốszereplôje egy szkizofréniával élő fiú, vagy Ian McEwan Ôrült szerelem címú múve (1997), amely a de Clerambaultszindrómával foglalkozik.

Roth szerint az irodalomelméletben a természettudományokhoz való közeledés (természetesen sok egyéb irány mellett) már az 1980-as évektôl megfigyelhetô, a nyelvi fordulat kifáradását és a pszichoanalitikus iskolák fokozatos hitelvesztését ${ }^{[21]}$ kíséri (Roth 2009). Maga a tendencia nem vezet megbízhatóbb módszerekhez és eredményekhez, mivel, ahogy Roth megjegyzi, redukcionista, hiszen mentális folyamatokat és problémákat kizárólag az agy folyamataival igyekszik magyarázni (Roth 2009). Ezzel a módszertani buktatóval Alva Noë hasonlata szerint ugyanazt a hibát követjük el, mintha egy autó múködését kizárólag a motor vizsgálatával igyekeznénk megérteni ${ }^{[22]}$ (Noë 2004: 211-212.).

A redukcionizmus fontos, noha ennél a múfajnál nem feltétlenül helytálló kritika. A neuroregények ugyanis nem az agy és az idegrendszer múködésére koncentrálnak, hanem sokkal inkább tudatábrázolásként kezelendôek, a korábbi hasonló témájú regényektôl ebbôl a szempontból abban különböznek, hogy a szereplók meghatározott mentális vagy idegrendszeri rendellenességgel élnek, így, bár Roth kimondottan új múfajként beszél a neuroregényrôl, az inkább a pszichológiai regény almúfajának tekinthetô. Ezekhez a múvekhez valóban hozzátartozik az adott rendellenesség tünettanának és biológiai hátterének ismerete, a történetek azonban nem ezek körül forognak. Ilyen szempontból a neuroregényt a tudományterületek fontos egyesülése színterének tekinthetjük, hiszen a történetek megírását valószínúsíthetôen gyakran ihleti vagy követi végig orvosi esetleírások és más szakszövegek tanulmányozása. ${ }^{[23]}$ Azt azonban Roth is elismeri, hogy mivel fiktív történetekrôl van szó, a narratívák megírásának fớ stratégiái az introspekció és mások megfigyelése, amelyek egyeznek például a szerinte hitelt vesztett pszichoanalízis módszereivel (Roth 2009). Marie-Laure Ryan szavaival szólva elkerülhetetlennek tûnik, hogy az elméleti és múvészi munkák, amelyek a humán tudományok illetve a kognitív- és idegtudományok kombinációját kísérlik meg, módszertanukat tekintve kényelmetlenül beszorulnak egyfelól a spekuláció és az interpretáció, másfelől a kísérleti és empirikus megközelítések közé (Schneider 2017: 485). Ugyanakkor az ilyen törekvések haszna és fontossága pontosan abban áll, hogy egyszerre több, egymástól meglehetôsen távol esố területtel foglalkoznak. Az irodalomelmélet, a filozófia és általánosságban a múvészet természetesen nem csupán a különböző pszichológiai problémák és mentális betegségek feltérképezésében bizonyulhat inspirációnak vagy akár alkalmazható elméletnek, hanem az egészséges tudat múködésének modellezésében is. ${ }^{[24]}$ A pszichiátriában és pszichológiában a narratív fordulat a pszichoterápiák fejlesztésében hasznosítja a narratív elméleteket az élettörténet és az önéletrajzi emlékezet 
vizsgálataiban. Mihail Bahtyin polifonikus regény elméletére és Nietzsche filozófiájára épít például a személyiségpszichológiában a Hubert Hermans nevéhez fưződő ún. dialogikus szelf elmélet ${ }^{[25]}$, amely a korábban ideálisnak tekintett, harmóniát és koherenciát hangsúlyozó modellel ellentétben az egészséges szelf alapvetố jellemzőiként tartja számon a szelfen belüli konfliktusokat és ellentmondásokat, illetve a lehetséges szelfpozíciók közötti folyamatos dialógust. ${ }^{[26]}$

Az irodalomelmélet egyes tézisein kívül maga az irodalom is fontos eszköze lehet például a pszichológiai vagy pszichiátriai kutatómunkának. Jay Hamm és munkatársai kiemelik, hogy mentális problémák esetében az adott állapot szubjektív oldalának megismerésében a legjobb eszköz a múvészet. ${ }^{[27]}$ Hamm és munkatársai Denis Johnson Jesus' Son címú novelláskötetét elemzik fiktív pszichózisnarratívaként (Hamm et al. 2014), példázva egyrészt, hogyan segítheti a pszichológusok munkáját fiktív történetek vizsgálata, másrészt azokat a kérdéseket, amelyek irodalmi múvek természettudományos módszerekkel és elméletekkel történô elemzése során felmerülnek. A novelláskötet elbeszélóje egy fiatal, drogfüggő férfi, akirôl az olvasó csak nagyon kevés információhoz jut. Hamm és munkatársai a szkizofrénia némely tüneteit vizsgálják az elbeszélésekben annak ellenére, hogy Johnson, a mú szerzője nem szenved ebben a betegségben, és a történetek narrátoráról sem derül ki ez a szövegekból. Hamm és munkatársai nem diagnosztizálják az elbeszélốt, mivel nem magát a betegséget, csupán egyes tünetek szujbektív élményét veszik górcsố alá. ${ }^{[28]}$ Problémásabb lehet Ronald Schleifer vállalkozása, mely során a Tourette-szindróma és a költői nyelv összefüggéseit kutatja egy neuroregény, Jonathan Lethem ${ }^{[29]}$ Arva Brooklynja segítségével ahelyett, hogy valódi Tourette-szindrómával élők beszédét vizsgálná (Schleifer 2001), így jogosan gyaníthatjuk, hogy Schleifer a regény elemzésével nem tesz mást, minthogy a költôi nyelvet a költôi nyelvvel veti össze.

Neuroregények esetében soha nem lehetünk benne teljesen biztosak, hogy a tudomány jelenlegi álláspontja szerint autentikus reprezentációt kapunk-e az adott betegséggel élók beszédérôl, nem is beszélve a tudatukról. Meg kell azonban jegyezni azt is, hogy maga a tény, hogy valaki szenved egy mentális betegségtôl, még szintén nem garantálja, hogy szubjektív tapasztalásainak leírására képes megtalálni a megfelelô szavakat, stílust és szerkezeteket. Ron Padgett költô a múvészi kreativitás hitelének védelmében csatlakozik a pszichológusok által is megfogalmazott érvhez, amikor kijelenti, hogy „egy dolog rosszat álmodni, és egy egészen másik úgy írni, mint Kafka” (Padgett 1997: 54). Általánosságban a múvészetrôl és jelen esetben az irodalomról végeredményben feltételeznünk kell, hogy képes mentális állapotokat megragadni és ábrázolni. Alva Noë szintén arra mutat rá, hogy a fenomenológiához hasonlóan a múvészetek feladata sem az, hogy egyszerúen ábrázolják a tapasztalást, hanem hogy megragadják a tapasztalásban a világ elérésének módozatait ${ }^{[30]}$ (Noë 2004: 176). Ehhez a feladathoz a neuroregényekben vizsgálható különböző mentális állapotok és zavarok miatt elidegenedett percepciók és az ezek segítségével megépített történetvilágok különösen hasznosak lehetnek.

Valószínúleg ebbôl a rövid bemutatásból is egyértelmúen látszik, hogy sem a neuronarratológia, sem a neuroregény nem foglalkozik radikálisan új kérdésekkel és problémákkal. Ilyen szempontból a neuroregény nem felváltotta a pszichológiai regényt, sokkal inkább egy új 
generációja a múfajnak, a neuronarratológia pedig a kognitív narratológia egy újabb ága. Mindkettố csupán azért tekinthetố újszerûnek, mert újabb, a bölcsészettudományban korábban szokatlan elméletek fényében vizsgálja a régi kérdéseket és témákat. Az ilyen törekvések a korábbi meglátásokat, például a narratívák gondolkodásban betöltött szerepét elsôsorban nem felülírni, hanem árnyalni igyekeznek (Kiss 2015: 44, Farmasi 2019, Schneider 2017).

Ennek lehetséges hozadéka például olyan narratológiai terminusok pontosítása, mint a fokalizáció vagy a (fokalizáló karakter benyomásain keresztül megkonstruált) narratív tér vagy idô. Ezek a fogalmak szorosan kötődnek az emberi észleléshez, és bár részletes elemzésekkel bírnak, definíciójuk sok esetben még azelött született, hogy az észlelés tudományos kutatása megkezdődött volna, és ezek integrálása, bár gyümölcsözőnek ígérkezik, még kevéssé valósult meg. Az elmúlt pár évben jelentek meg olyan kutatások, amelyek az emberi test fiziológiájával és a kogníció összetettségével foglalkoznak. Ilyen Richard Walsh tanulmánya, amelyben a narratív megértés folyamatát bontja „alkotóelemeire,” amelyek között fontos szerepet tulajdonít a nemverbális, szomatoszenzoros kognitív folyamatoknak. Példaként a térészlelés és a narratív intelligencia (együtt)múködését vizsgálja az olvasás folyamatában (2017). Kiss Miklós a narratív filmek cselekményszerkezeteit igyekszik jobban megérteni képi sémák ${ }^{[31]}$ segítségével. Megközelítésére a biokulturális (bio-cultural) jelzôt használja, ami arra utal, hogy a módszer elismeri, hogy a kogníció alakításában biológiai, evolúciós, és kulturális tényezốk egyaránt részt vesznek. Egy másik kutatás eredményeképpen Marco Caracciolo arra jut, hogy A lé meg a Lola (Lola Rent. Tom Tykwer, 1999) ${ }^{[32]}$ címú film fôszereplôjén keresztül a narratívájába építi a futás és a pulzus ritmusát, ezen keresztül a nézô a „testében érezheti” a történet fố tényezôjét, a (narratív) idô (rohamos) múlását (Caracciolo 2014: 65). Az ilyen jellegú kutatások többek közt az emberi test és tudat, illetve a humán és természettudományos szemléletek közötti egyensúly kialakítására törekszenek.

\section{A tudás megszerzésének módja(i)}

Amikor Tzvetan Todorov megalkotta a „narratologie” terminust 1969-ben, a narratológiát a történetek tudományaként határozta meg (Todorov 1969: 10). Fontos volt a természettudományokhoz igazítani a megközelítést, mert ez legitimálta, hogy univerzális kijelentéseket lehessen tenni a történetekrôl, ami a klasszikus narratológia jellemzôje. Todorov a strukturalizmus szabályai szerint úgy gondolta, hogy a narratívák vizsgálatának célja a történet mögötti absztrakt struktúrák megértése, amelynek az adott történet csak egyik lehetséges manifesztációja (Todorov 1969: 2099). A cél az volt, hogy a történet tartalma helyett absztrakt szerkezeti sajátosságokat figyeljenek meg, részben azért, mert ezek teszik lehetôvé azt, hogy a narratológia is szert tegyen a természettudományok sajátos következetességére. ${ }^{[33]} \mathrm{A}$ tudás megszerzésének módozatai tekintetében a narratológiának így sajátos öröksége van, mivel módszereiben sokáig igyekezett a természettudományokra hasonlítani, a tesztelhetôség vagy a 
jövôbeli eredményekkel kapcsolatos következtetések azonban ekkor sem jellemezték.

Roy Sommer a strukturalista hagyomány helyzetérôl értekezik, és maga is amellett érvel, hogy ha a más tudományterületekkel való összeegyeztethetôség garantálhatja egy tudomány fennmaradását, akkor a narratológiának éppen a (strukturalista) múltja lehet a jövôje. Sommer a klasszikus narratológia fogalmainak és elméleteinek szem elôtt tartása mellett a jelenben párhuzamosan zajló, narratívák kutatását érintô vizsgálódások összeegyeztethetôséget is fontosnak tartja. Ilyen szempontból a Schmid által népszerúsített „tiszta” (klasszikus) narratológia módszerei éppen a más területekkel való együttmúködésnek és az ezáltal történô „beszennyeződésnek” adnak lehetôséget. A tanulmány utolsó része arra tér ki, miért lehet fontos feltétele az összeegyeztethetôség egy tudományág sikerességének.

A tudományfilozófia Sommer szerint jóval többet foglalkozik a természettudományokkal, mint a bölcsészettel, és ez az eltolódás a „két kultúra” elszigeteltségét erôsíti (Sommer 2017: 595). A narratív elméletek módszerei és az általuk termelt tudás Sommer hipotézise szerint sajátos „dupla szerkezetbe" rendeződnek (Sommer 2017: 596), lévén hogy a narratológusok produktívan használják a megismerés egymástól radikálisan különböző forrásait, így egyfelôl az intuitív, esztétikai élmény nyújtotta tudást, másrészt az absztrakt és szisztematikus tudást, amit az elóbbi, intuitív tudásnak a narratíva és a narrativitás fogalmaihoz való viszonyát vizsgálva állítanak elô (Sommer 2017: 596). Sommer ezzel arra a tényre utal, hogy a narratológus munkájának része az általa elemzett regény vagy film befogadása, bár a szubjektív, befogadói élmény az elemzési munka folyamatát nem feltétlenül határozza meg. Fontos az is, hogy az irodalmi múvek és a filmek elemzései messze nem fedik le a narratív elméletek által tárgyalt szövegek összességét. Számos olyan narratív vizsgálat létezik, amelynek nem része a fenti értelemben vett esztétikai élmény.

Sommer szerint a fontos különbség a „két kultúra” között, hogy a szubjektív tapasztalatokat nem értékelik egyformán. A tudományfilozófia elismeri, hogy az intuíciónak szerepe van a „kemény” tudományok munkájában is, legalábbis annak elsô szakaszában, ahol inkább a tudományos felfedezés körülményeként tekintünk rá, s nem annak szerves részéként. Önmagában nincs értéke, inkább egy afféle kezdeti, „misztikus” ponton lehet jelen a kutatásban, amikor megkezdôdik a hipotézisek és a kutatási módszer fejlesztése. Ezzel ellentétben az irodalomelméletben az esztétikai élmény külön jelentôséggel bír (Sommer 2017: 596).

Siri Hustvedt (Luisiana Channel) szerint azonban az intuitív, ösztönszerú felismerések nem csupán a humán tudományokban, hanem a természettudományos kutatásokban, sốt tanulmányok írásakor is jelen vannak. Hustvedt arról az élményrôl beszél, amely során az írók úgy érzik, hogy az általuk írt múvet nem teljesen maguk alkotják, hanem a mú „magát alakítja”. Hustvedt ugyanezt a tudattalan tényezôt tapasztalja tudományos szövegek írása közben is, ahogy erról több kutató is szintén beszámolt már (Luisiana Channel). A folyamat leírása, ti. hogy egy író vagy egy kutató ösztönösen dolgozik, és „megérzi”, hogy amit kitalál, az hiteles vagy helyes, az implicit memória múködésével foglalkozó kutatások eredményeivel hozható összefüggésbe. ${ }^{[34]}$ Ezek a munkák az 
implicit memória jelentôségét az agy predikciós képességében látják (Baddeley et al. 2010: 508). Ilyen ösztönös megérzéseink csak olyan dolgokkal kapcsolatban tudnak valóban múködni, amelyekben nagy tapasztalattal bírunk, vagy amelyeket jól ismerünk (Németh 2014). Ebból a szempontból a tudás „elôállításának” két, hagyományosan ellentétesnek feltételezett formája között tulajdonképpen nincs választóvonal, hanem ugyanarról a folyamatról van szó.

A cikkem címében szereplő „mesterséges határok” értelmezés Mark Turnertôl származik (Hamilton, Schneider 2002: 653), aki nem egyszerúen különböző tudományterületek közötti, hanem a kognitív tudomány és a múvészet, pontosabban irodalom közötti határokra vonatkoztatja. Turner és általánosságban a kognitív poétika szerint az irodalom kognitív, az elme irodalmi ${ }^{[35]}$, és a kettô közötti határok mesterségesek (Hamilton, Schneider 2002: 653). A történetekben való gondolkodás a kognitív narratológia szerint az emberi kogníció egyik alapvetô része (Hamilton, Schneider 2002: 652), az irodalmat így hiba elválasztani a kogníció más folyamataitól. Az irodalom és a mindennapi kommunikáció a megtestesült elme elméletei szerint több tekintetben ${ }^{[36]}$ ugyanazokon az elveken múködik, és az irodalmat alapvetôen ugyanúgy kellene vizsgálni, ahogy az emberi gondolkodás egyéb formáit vizsgáljuk (Hamilton, Schneider 2002: 647), vagy legalábbis vizsgálatakor tekintetbe kell venni az emberi tudat egyéb múködéseit. [37 ]

\section{Konklúzió helyett}

Megjegyzendô, hogy különbséget kell tenni az eredmények összeegyeztethetősége és az együttmúködés, ill. a különböző értelmezői keretek és módszerek összemosása között. Az utóbbi nem volna gyümölcsözô, a „történetek tudománya” például objektív és szisztematikus elméletek kidolgozására törekedett, arra viszont soha nem, hogy tesztelhetố megállapításokat és következtetéseket hozzon létre. A narratológusok célja nem az, hogy elméleteiket egyértelmúen bizonyítani vagy cáfolni lehessen (Sommer 2017: 605), sốt nem is az, hogy munkájukkal a narratológia „egyenes vonalon” elôrefelé haladjon. Az 1980-as évektôl a (posztklasszikus) narratológiában, sốt, az irodalomelméletben is változás következett be, minek során (leegyszerúsítve) a strukturalista szemléletet többek között felváltotta a kultúratudomány (Sommer 2017: 602), miközben a párhuzamosan épülö kognitív narratológia módszereiben többen megfigyelték már, hogy sok tekintetben visszanyúl a strukturalista megközelítéshez.

Túlzás volna azt állítani, hogy a kognitív narratológia mutathatja meg a „kiutat” a bábelizált állapotból, de az interdiszciplinaritása fontos lehet. Elképzelhetô, hogy a többi tudománnyal való összeegyeztethetôség lehet a narratológia gyümölcsöző jövôjének garanciája, mert, ahogy azt Sommer belátja, a narratív elméletek önmagukban sosem magyarázhatnak meg mindent, ami magyarázatra szorul a narratívákkal kapcsolatosan (Sommer 2017: 603), emellett azt is fenntartja, hogy más területek is profitálhatnak a narratív elméletek eredményeiből, sôt, akár függhetnek is azoktól (Sommer 2017: 603). Ezt a helyzetet Sommer szerint a strukturalizmus egyéb területekkel könnyen összeegyeztethetô fogalmai és modelljei mellett az teszi lehetôvé, hogy nem függ az 
elemzéseinek tárgyaitól, és nincs rögzített ideológiai pozíciója.

A formalizmus, az elsô szisztematikus irodalomelméleti iskola úttörôi egy olyan idôszakban fogalmaztak meg kritikát, amikor a diszciplináris határok közötti átjárás ${ }^{[38]}$ gyakori volt.

„Specifikus irodalmi vizsgálódás” hiányában Jakobson megfigyelése szerint az irodalmi múveket egyéb kutatások „másodrendú dokumentumaiként” kezelték, Tinyanov pedig az irodalomelméletet önállótlan, más tudományoktól függő „gyarmatosított” szerepben látta (Nyírô 1970: 146). A különböző tudományterületek és módszerek keveredése ma számtalan területen egy ehhez hasonló helyzetet vetíthet elôre, ennek az elôjeleként értelmezhetố a narratológusok által „fertôzésnek” titulált probléma. A diszciplináris határok 20. századi, esetenként túlértékelt szerepének pozitív hozadéka lehet az, hogy ez a veszély feltehetóleg már nem fenyegethet, azaz bármilyen módszerrel és bármilyen fókusszal is folyjanak kutatások, a bábelizáció ellenére sem volna lehetséges, hogy egyes tudományterületek gyarmati szerepbe kerüljenek vissza, a más tudományoktól való függés legalábbis nem jelenthet automatikusan alárendelt szerepet. ${ }^{[39]} \mathrm{A}$ korábban idézett Martínez, Sommer és Heinen által írott tanulmányok kifejezetten a narratológiára tett meglátásai mind igazak általánosságban a többi tudományterületre is, és ez a Sommer által hangsúlyozott összeegyeztethetôségre is igaz lehet. A megközelítések bábeli zúrzavara részben a diszciplináris határok sorozatos áthágásának eredménye, és bár valószínúleg lehetetlen megjósolni, hogy hova vezet, hasznos lehet átgondolni, hogy milyen fajta kérdésfelvetéseknek és milyen kutatói módszereknek és stratégiáknak kedvez, és milyen lehetôségekkel.

1. A kutatást az EFOP-3.6.1-16-2016-00008 azonosítójú, EU társfinanszírozású projekt támogatta, a szerző a Mentális Betegségek Megelőzése Interdiszciplináris Kutatócsoport (SZTE) tagja.

2. A két tudományterület viszonyának tárgyalásánál a bölcsészet oldalán szokás megemlíteni a múvészeteket. Ezt teszi a „két kultúra” kifejezés megalkotója, C. P. Snow, amikor az elméleti fizikában való jártasságot az irodalomelmélet helyett Shakespeare munkásságának ismeretével állítja párhuzamba (Snow 2012: 15), és Elena Gomel narratológus, aki a két terület viszonyának tárgyalásánál a humán tudományok címszó alatt szintén irodalomról beszél (Gomel 2014: 8).

3. Emlékezetkutatásban használt tesztalanyok.

4. Az agyi képalkotó diagnosztikai eszközök által szolgáltatott adatok sem közvetlenül árulkodnak az agy múködésének mikéntjérôl, a miértjérôl pedig olykor több kérdést vetnek fel, mint amennyire választ adnak.

5. https://www.facebook.com/events/467814133716498/permalink/474934153004496/

6. Ugyanez lehetett az elvárása a posztkarteziánus test, elme és környezet dinamikus kapcsolatát feltételező nézônek is. A kogníció posztkarteziánus elméleteirôl lásd bővebben: Damasio (1995), Shapiro (2011), Chemero (2009), Lakoff, Johnson (1999).

7. Ilyenek ma a mesterséges intelligencia kutatás, különösen a robotika kísérletei. [-A szerzô megj.]

8. A közvéleménynek a filozófiával és egyéb humán és társadalomtudományokkal szemben is megvannak az elôítéletei, ezt az elmúlt években legerôsebben a feminizmust és a genderelméleteket övezô, esetenként politikai színezetú viták mutatták meg. [-A szerző megj.]

9. Jóllehet ez a jelenség nem kizárólag a narratív elméletek különlegessége, hanem a kortárs tudományok általános jellemzője. 
10. A tanulmányban felsorolt, a narratológiai kutatásokat hátráltató tényezók korántsem specifikus problémák. Martínez tárgyalja többek közt a tudományos eredmények publikálásának és terjesztésének nehézségeit; a nyelvi korlátokat, ti. egy tanulmány sikerességét nagyban befolyásolja, hogy megjelenik-e angolul; vagy azt a jelenséget, hogy a kevésbé népszerú kutatási témák recepciója szegényes, míg más témák és megközelítések egyenesen túltárgyaltak. Ezek a problémák vélhetôen minden tudományterületen jelen vannak.

11. A kognitív irodalomelméletrôl lásd bôvebben: Horváth Márta, Szabó Erzsébet (szerk.) (2013): Helikon irodalomtudományi szemle: Kognitív irodalomtudomány, 2. Budapest.

12. Narratív filmek kognitivista (és egyéb) megközelítéseinek lényegérôl és viszonyáról lásd: Füzi (2008), a megtestesült kogníció és a mozi(nézô) kapcsolatáról: Coegnarts és Kravanja (2015).

13. Ehmann Bea pszichológus mutat rá, hogy a narratíva kifejezést használják a pszichológiában bármilyen hosszabb, kliensek vagy kutatási alanyok alkotta szövegre, és pl. egyéb szövegtípusok helyett teszteredményekkel és más kutatási módszerekkel kinyert adatoktól különböztetik meg (Ehmann 2002: 74).

14. A feltételes módot a tanulmány elején említett tendencia miatt használom, miszerint a narratív elméletek különösen a humán tudományokon kívül egymástól elszigetelve, minden kommunikáció nélkül épülnek.

15. Fontos lehet, hogy Ramachandran gondolkodását nagyban meghatározza India kulturális közege, ahol a múvészetek, a filozófia és a természettudományok nem határolódnak el egymástól radikálisan.

16. Errôl a területrôl lásd bôvebben: Chatterjee (2014)

17. Az emberi test szerepének vizsgálata a human tudományokban önmagában nem új törekvés. A huszadik században megnövekedett érdeklődés övezi a testet: a fenomenológia, a pszichoanalízis, a társadalom- és kultúratudományok egyaránt intenzíven foglalkoznak vele. Errôl a tendenciáról lásd: Kiss (2005), Tóth (2009), Kérchy (2009).

18. Az, hogy Roth kizárólag prózával foglalkozik, némileg önkényes választás eredményének tûnik. A költészetben, a drámában, és a filmben szintén könnyen találhatunk mentális problémákkal, rendellenességekkel foglalkozó múveket, amelyek hasonló figyelmet és elemzéseket érdemelnek.

19. Az Amerikai Egyesült Államokban ebben az idôszakban tudatosan tettek jelentôs erôfeszítéseket az agykutatás elősegítésére és ezen kutatások eredményeinek népszerúsítésére.

20. E tendencia része például a törvényszéki orvostudomány népszerúvé válása az amerikai populáris kultúrában (Steenberg 2012).

21. Noha ajánlott az empirikus vizsgálatok eredményeit is szkeptikusan kezelni, a hitelvesztés oka, hogy a természettudományok módszereivel ellentétben a pszichoanalízis rengeteg híres elméletét, mint például Freud Álomfejtés (1899) címú múvének következtetéseit vagy Lacan ezekre is építô jelölő folyamatot leíró modelljét lehetetlen tesztelni.

22. Egy autó esetében tudjuk, hogy a múködését szervesen befolyásolja a „teste” minden része, sôt, a környezete is: az autók nem múködnek kerék nélkül, víz alatt vagy a tetejükre állítva. A megtestesült elme (posztkarteziánus) elméletei szerint a tudat múködését hasonló mértékben befolyásolhatják az emberi test különbözô aspektusai és folyamatai, bár ez a logika a tudat meghatározásainak hosszú történetei között jóval kevésbé jellemző, mint az autó esetében.

23. Jonathan Lethem például az Arva Brooklyn megírása elött tanulmányozta Oliver Sacks Tourette szindrómáról szóló írásait (Köves 2011).

24. Ez különösen értékes lehetôség, hiszen pl. a pszicholingvisztika vagy a neurológia a tudat és az idegrendszer egészséges múködésére is leggyakrabban deficitek vizsgálatából következtet, így merülhet fel idônként az a lehetôség, hogy ezek hibás múködésérôl már-már többet tudunk, mint az egészséges 
folyamataikról.

25. Lásd pl. Hermans (2012).

26. Edward Branigan kognitivista elméletekre támaszkodva szintén ezekkel a jellemzókkel írja le a filmnézô befogadói helyzetét (2006).

27. A freudi pszichoanalízis ennél jóval korábban már kísérleteket tett rá, hogy a lelki apparátust a korábban patologikusnak nevezett állapotok vizsgálatával, gyakran múvészeteken keresztül értse meg.

28. A diagnózis hiánya nem módszertani hiba, hiszen a szkizofréniának jelenleg nincs általánosan elismert specifikus tünete, azaz minden tünete megtalálható más kórképekben is, ráadásul a tünetek idôvel változhatnak ugyanazon személy esetében is (American Psychiatric Association 2013: 87).

29. Lethem szintén egészséges.

30. Ugyanezzel a céllal vizsgálja a jelhasználatot a szemiotika is, Saussure szemiológiája nyomán nem a jelentés érdekli, hanem az a folyamat, amelynek eredményeként a jelentés létrejön.

31. A kogníciót szervezô, a test és a környezet közötti interakciók mintázataira épülô dinamikus gestaltok. Ezekrôl bóvebben lásd: Hampe (2005).

32. A mozgás történetben betöltött szerepét hangsúlyozza az is, hogy a "futni” kifejezés a film címének eredetijében (Lola rennt) és angol fordításában (Run Lola Run) is szerepel.

33. Ez az attitûd nem csak a narratológiára jellemzô, a huszadik század elsô felében a teljes modern irodalomelmélet igyekezett tudományos „eszközöket” fejleszteni.

34. A hétköznapokban olyan események tartoznak ide, amikor múködésbe lép a „hatodik érzékünk”, és látszólag megmagyarázhatatlan előérzeteink támadnak, például elöre megérezzük egy hozzátartozónk halálát. A kognitív pszichológia szerint az ilyen intuitív benyomások annak köszönhetók, hogy tudattalanul változást érzékelünk az észleléseink megszokott mintázatában, a fenti példában egy jól ismert és gyakran látott beteg rokonunk viselkedésének egész rendszerében: lélegzésének ritmusában, pupillája mozgásában, az illatában. Ezek az illetô halálának előjelei. Az ilyen változások észlelése ugyan nem tudatos, de mivel ezek által a tapasztalásunk eltér a megszokottól, egyszerúen az a benyomásunk, hogy „valami nem stimmel”. A megérzések ennek az érzésnek az interpretációiként érthetôk meg (Németh 2014). Véleményem szerint hasonló módon tudhatja egy tapasztalt író vagy kutató, hogy amit alkot, az mennyire illeszkedik a számtalan releváns tapasztalata által kiadott mintázatba: a jól megírt történetek, illetve a jól levezetett érvelések vagy kutatások mintái közé. Megjegyzendő, hogy a mindennapi megérzéseink nagy része hamis, így lehetséges, hogy ez a múvészeknél és tudósoknál sincs másképp, azonban ahogy Németh kifejti, hiába a téves megérzések aránya, hosszú távon jellemzően csak azokra az alkalmakra emlékszünk, amikor a jóslataink és megérzéseink múködtek (Németh 2014).

35. Turner az irodalomelmélet, a nyelvészet és a kognitív tudomány ötvözésének segítségével az irodalomelméletben használatos költői képek és szerkezetek müködésével foglalkozott, mint a parabola vagy a metafora. Elmélete szerint ezen mechanizmusok szerint szerveződnek a mentális folyamataink, tehát az irodalmi kifejezésmódok és a hétköznapi gondolkodás ugyanazon elvek szerint múködnek (Hamilton, Schneider 2002: 647).

36. Ilyennek tekinti Turner a metaforákat $(2000,1996)$. Kiss Miklós a képi sémák narratív formákban betöltött szerepét vizsgálja narratív filmekben (2015), ezek a sémák jelen vannak az irodalomban is.

37. Walsh például hasonló elvek szerint próbálja modellezni az olvasást a térészlelés folyamatainak számbavételével (2017).

38. A formalisták által kritizált Alexandr Potebnya például egyszerre végzett irodalmi, nyelvészeti és lélektani elemzést.

39. Az alárendelt szereprôl kutatási módszerek kapcsán beszélek, ahogy az idézett formalisták is ezekre 
utalhattak, legalábbis a mozgalmaik elején. Ôk kezdetben azzal küszködtek, hogy nem volt elméleti eszközük ahhoz, ahogy ôk elképzelték a munkájukat, és ilyen szempontból kényszerültek irodalommal valamilyen más tudományterület „alatt” foglalkozni. Amit ebben az idôszakban kialakítottak, az olyan alapot adott az irodalomelméletnek, aminek köszönhetôen módszertani vagy elméleti szempontból az már nem kerülhet vissza a formalizmus elootti helyzetébe. A „gyarmat” kifejezés utalhat tudomány- és intézménypolitikai folyamatokra is, amelyekkel késóbb a formalisták is szembetalálták magukat - ezek vizsgálata külön tanulmányt érdemelne.

\section{Irodalomjegyzék}

- American Psychiatric Association (2013): Diagnostic and statistical manual of mental disorders (5th ed.). Washington. https://doi.org/10.1176/appi.books.9780890425596

- Baddeley, Alan, Michael W. Eysenck, Michael C. Anderson (2010): Emlékezet. Ford. Racsmány Mihály. Budapest, Akadémiai Kiadó.

- Branigan, Edward (2011): Narráció. Ford. Füzi Izabella. In Vizuális és verbális narráció. Szöveggyújtemény. Szerk. Füzi Izabella. Szeged, Pompeji, 39-70.

- Caracciolo, Marco (2014): Tell-Tale Rhythms: Embodiment and Narrative Discourse. In Storyworlds: A Journal of Narrative Studies, 6. 2: 49-73. https://doi.org/10.5250/storyworlds.6.2.0049

- Changeux, Jean-Pierre, Paul Ricoeur (2001): A természet és a szabályok. Budapest, Osiris Kiadó. Ford. Pléh Csaba.

- Chatterjee, Anjan (2014): The Aesthetic Brain. How We Evolved to Desire Beauty and Enjoy Art. Oxford, Oxford University Press. https://doi.org/10.1093/acprof:oso/9780199811809.001.0001

- Chemero, Anthony (2009): Radical Embodied Cognitive Science. Cambridge, Massachusetts, The MIT Press. https://doi.org/10.7551/mitpress/8367.001.0001

- Coegnarts, Maarten, Peter Kravanja (szerk.) (2015): Embodied Cognition and Cinema. Leuven, Leuven University Press.

- Damasio, Antonio (1995): Descartes'Error: Emotion, Reason and the Human Brain. New York, Avon Books.

- Ehmann, Bea (2002): A szöveg mélyén: A pszichológiai tartalomelemzés. Budapest. Új Mandátum Könyvkiadó.

- Farmasi, Lilla (2019): "Söbb a temminél”. A neuronarratológia lehetôségei és egy Touretteszindrómás tudaton keresztül épült történetvilág In Horváth Márta, Szabó Erzsébet (szerk.): Hogyan olvasunk krimit? Új perspektívák a detektívtörténet kutatásában. Budapest, Ráció Kiadó, 130156.

- Füzi Izabella (2008): A narratív film elméletei. Apertúra: Filmelméleti és filtörténeti online szakfolyóirat, 2008. tavasz. URL: http://apertura.hu/2008/tavasz/fuzi

- Hamilton, Craig A., Schneider, Ralf (2002): From Iser to Turner and Beyond: Reception Theory Meets Cognitive Criticism. Style, 36. 4: 640-658.

- Hamm, Jay A., Bethany L Leonhardt, Rebecca L Fogley, Paul H Lysaker (2014): Literature as an exploration of the phenomenology of schizophrenia. Disorder and recovery in Denis 
Johnson's Jesus' Son. Medical Humanities, 40. 2.

https://doi.org/10.1136/medhum-2013-010464

- Hampe, Beate, Joseph E. Grady (szerk.) (2005): From Perception to Meaning: Image Schemas in Cognitive Linguistics. Mouton de Gruyter. Berlin.

https://doi.org/10.1515/9783110197532.0.1

- Heinen, Sandra, Roy Sommer (szerk.) (2009): Narratology in the Age of Cross-Disciplinary Narrative Research. Berlin, Walter de Gruyter.

https://doi.org/10.1515/9783110222432

- Herman, David (2009): Basic Elements of Narrative. West Sussex, Wiley-Blackwell. https://doi.org/10.1002/97814444305920

- Hermans, H.J.M., Gieser, T. (szerk.) (2012): Handbook of Dialogical Self Theory. Cambridge. Cambridge University Press. https://doi.org/10.1017/CBO9781139030434

- Horváth Márta, Szabó Erzsébet (szerk.) (2013): Helikon irodalomtudományi szemle: Kognitív irodalomtudomány, 2.

- Hyvärinen, Matti (2010): Revisiting the Narrative Turns. Life Writing, 7. 1. 69-82. https://doi.org/10.1080/14484520903342957

- Gomel, Elena (2014): Narrative Space and Time. Representing Impossible Topologies in Literature. New York, Routledge. https://doi.org/10.4324/9781315889528

- Kérchy, Anna (2009): Tapogatózások: A test elméleteinek alakzatai. Apertúra: Filmelméleti és filtörténeti online szakfolyóirat, 2009. tél. URL: http://apertura.hu/2009/tel/kerchy

- Kiss, Attila (2005): Vérszemiotika: a test kora modern és posztmodern színházai. Jelenkor: Irodalmi és müvészeti folyóirat, 48.6, 619-632. URL: http://www.jelenkor.net/archivum/cikk/796/verszemiotika-a-test-kora-modern-esposztmodern-szinhaza

- Kiss, Miklós (2015): Film Narrative and Embodied Cognition: The Impact of Image Schemas on Narrative Film. In Coegnarts, Maarten, Peter Kravanja (szerk.): Embodied Cognition and Cinema. Leuven, Leuven University Press, 43-61.

- Köves, Gábor (2011): A betegség neve: Brooklyn - Jonathan Lethem író. Magyar Narancs. URL: http://magyarnarancs.hu/konyv/jonathan-lethem-iro-52319

- Lakoff, George, Mark Johnson (1999): Philosophy In The Flesh: The Embodied Mind And Its Challenge To Western Thought. New York, Basic Books.

- Louisiana Channel. Siri Hustvedt Interview: Art and Science. 2018. március 8. https://www.youtube.com/watch?v=XvdoFBEctPI\&t=363s\&pbjreload=10

- Martínez, Matías (2012): Dos Passos instead of Goethe! Some observations on how the history of narratology is and ought to be conceptualized. DIEGESIS. Interdisziplinäres E-Journal für Erzählforschung / Interdisciplinary E-Journal for Narrative Research, 1.1. 134-142.

- Nabokov, Vladimir (2011): Strong Opinions. London, Penguin Classics.

- Németh Dezső (2014): Memória és intuíció. Karrierközpont ELTE. Harmadik Kor Egyeteme. URL: https://www.youtube.com/watch?v=g98VsM9Rc-I\&t=3891s\&pbjreload=10

- Noë, Alva (2004): Action in Perception. The MIT Press.

- Nünning, Ansgar (2003): Narratology or Narratologies? Taking Stock of Recent Developments, Critique and Modest Proposals for Future Usages of the Term. In Kindt, Tom, 
Hans-Harald Müller (szerk.): What Is Narratology. Questions and Answers Regarding the Status of a Theory. Walter de Gruyter. Berlin, 239-276.

https://doi.org/10.1515/9783110202069.239

- Nyírố Lajos (szerk.) (1970): Irodalomtudomány: Tanulmányok a XX. századi irodalomtudomány irányzatairól. Budapest, Akadémiai Kiadó.

- Ramachandran, V. S. (2012): The Tell-Tale Brain: Unlocking the Mystery of Human Nature. London, Cornerstone.

- Roth, Marco (2009): Rise of the Neuronovel. A specter is haunting the contemporary novel. n+1 Magazine, https://nplusonemag.com/issue-8/essays/the-rise-of-the-neuronovel/. Letöltés dátuma: 2018. 04. 28.

- Ryan, Kevin (2012): A Critical History of the Embodied Cognitive Research Paradigm. A review of Lawrence Shapiro's Embodied Cognition. AVANT, III. 1. 172-175.

- Schleifer, Ronald (2001): The Poetics of Tourette Syndrome: Language, Neurobiology, and Poetry. New Literary History, 32. (2001/3.), 563-584.

https://doi.org/10.1353/nlh.2001.0044

- Schneider, Ralf (2017): Is There a Future for Neuro-Narratology? Thoughts on the Meeting of Cognitive Narratology and Neuroaesthetics. In Per Krogh Hansen et al. (szerk.): Emerging Vectors of Narratology. Berlin, De Gruyter, 479-496.

https://doi.org/10.1515/9783110555158-023

- Shapiro, Lawrence (2011): Embodied Cognition. London, Routledge. https://doi.org/10.4324/9780203850664

- Shen, Dan (2005): Why Contextual and Formal Narratologies Need Each Other. Journal of Narrative Theory, 35.2. 141-71.

https://doi.org/10.1353/jnt.2006.0007

- Snow, C. P. (2012): The Two Cultures. Cambridge, Cambridge University Press.

- Sommer, Roy (2017): The Future of Narratology's Past: A Contribution to Metanarratology. In Per Krogh Hansen et al. (szerk.): Emerging Vectors of Narratology. Berlin, De Gruyter, 593-608. https://doi.org/10.1515/9783110555158-027

- Steenberg, Lindsay (2012): Forensic Science in Contemporary American Popular Culture: Gender, Crime, and Science. New York, Routledge. https://doi.org/10.4324/9780203082126

- Szokolszky, Ágnes (1998): A tudomány metamorfózisa és a kognitív tudomány: Posztkarteziánus alternatívák. In Pléh Csaba (szerk.) Megismeréstudomány és mesterséges intelligencia. Budapest, Akadémiai Kiadó, 273-295.

- Todorov, Tzvetan (1969): Grammaire du Décaméron. The Hague, Mouton.

- Tóth Zoltán János (2009): Egy kiállítás (test)képei: Bodies - The Exhibition. Apertúra: Filmelméleti és filtörténeti online szakfolyóirat, 2009. tél. URL: http://apertura.hu/2009/tel/tothz

- Turner, Mark (2000): Death is the Mother of Beauty. Mind, Metaphor, Criticism. Christchurch, Cybereditions Corporation.

- Turner, Mark (1996): The Literary Mind. Oxford, Oxford University Press.

- Walsh, Richard (2017): Beyond Fictional Worlds: Narrative and Spatial Cognition. In Per Krogh Hansen et al. (szerk.): Emerging Vectors of Narratology. Berlin, De Gruyter, 461-478. https://doi.org/10.1515/9783110555158-022 
(C) Apertúra, 2019. tavasz | www.apertura.hu

webcím: https://www.apertura.hu/2019/tavasz/farmasi-mesterseges-hatarok-a-

termeszettudomanyok-es-human-tudomanyok-viszonyarol-eredmenyeirol-es-modszereirol/

https://doi.org/10.31176/apertura.2019.14.3.6

(Q)opertúro 